\title{
Article
}

|||||||||||||||||||||||||||||||||||||||||||

\section{Characteristics of Oxygen Stable Isotopic Ratio in Precipitations in Niigata Prefecture, Japan}

\author{
Chong Li, Naoki Kano*, Yuichi Ueno, Mitsuru Hanabusa, \\ Yurong Jiao, Hiroshi Imaizumi* and Naoki Watanabe** \\ Graduate School of Science and Technology, Niigata University \\ * Faculty of Engineering, Niigata University \\ ** Research Center for Natural Hazards and Disaster Recovery, Niigata University \\ 2-8050 Ikarashi, Nishi-ku, Niigata-shi, Niigata Pref. 950-2181, Japan
}

Received September 30, 2009

\begin{abstract}
Time-course of oxygen stable isotopic ratios (i.e., $\delta^{18} \mathrm{O}$ ) as well as annual or seasonal variation of $\delta^{18} \mathrm{O}$ has been examined to investigate the sources, the passing route and characteristics of precipitations in Niigata Prefecture. The precipitation samples have been mainly collected with a filtrating bulk sampler at the rooftop of Niigata University from 1999 to 2008. Furthermore, backward trajectories analyses have been also conducted for these samples taken sequentially for a short period.

Consequently, the following features have been mainly clarified for the precipitations in Niigata Prefecture. (1) The $\delta^{18} \mathrm{O}$ values varied between $-25.14 \%$ and $-1.60 \%$, while the mean value of $\delta^{18} \mathrm{O}$ in each year was from $-8.37 \%$ (in 2006) to $-7.33 \%$ (in 2001). (2) As for the comparison among sampling points, the mean value of $\delta^{18} \mathrm{O}$ at seaside spots (i.e., Niigata City and Joetsu City) or marine spots (i.e., Sado City) is larger than that of inland spots (Shitada Village and Nagaoka City). (3) $\delta^{18} \mathrm{O}$ value was generally small in the rainy season, and relatively large in summer, and small in winter. (4) Decreasing $\delta^{18} \mathrm{O}$ content with time, as predicted by Rayleigh models of atmospheric vapor condensation, is a predominant feature of sequentially sampled rainfalls, particularly for precipitations taken during passage of typhoons.
\end{abstract}

Key Words : precipitation, oxygen stable isotopic ratio, sequentially sampled rainfall, backward trajectories analysis, Niigata Prefecture, Japan

\section{Introduction}

Oxygen and hydrogen isotope ratios (i.e., $\delta^{18} \mathrm{O}$, $\delta$ D) are widely used to investigate global or local hydrological cycle and to trace the origin and evolution of water ${ }^{1-4)}$. The stable isotopic compositions of precipitations vary with physical-chemical conditions such as evaporation and condensation in hydrological $\mathrm{cycle}^{1,3), 4)}$. It is considered that $\delta^{18} \mathrm{O}, \delta \mathrm{D}$ of precipitation reflect the origin of the atmospheric vapor and the conditions of precipitation formation above the sampling site. Thus, the isotopic variations of individual precipitation allow us to assess gradual or abrupt changes in the meteorological conditions governing the precipitation formation $^{7}$.

It is suggested that the $\delta^{18} \mathrm{O}$ value of the precipitation is correlated with the air temperature of the place where the precipitation is formed ${ }^{5,8), 9)}$. Hence, estimating time-course of $\delta^{18} \mathrm{O}$ in individual precipitation for a short period is important from the standpoint of the meteorology as well as investigating annual or seasonal behavior of $\delta^{18} \mathrm{O}$.

Niigata Prefecture is located in the geo- 


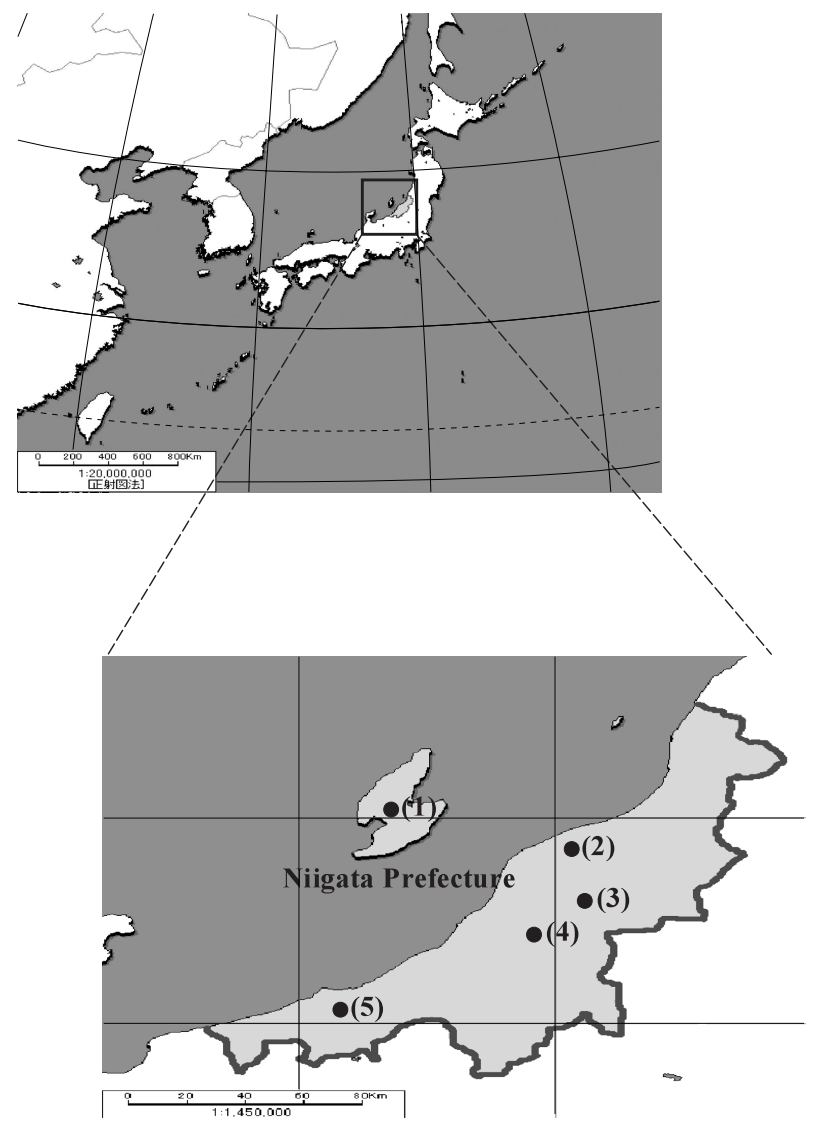

Fig. 1 Location of sampling points in Niigata Prefecture.

(1) : Sado City, (2) : Niigata City, (3) : Shitada Village,

(4) : Nagaoka City, (5) : Joetsu City.

graphic position where the influence of monsoon and/or the transportable components from the continent of China was fairly large. Moreover, a large amount of snow falls every year in winter season. Thus, isotopic and chemical investigation of the precipitation samples is significant for the understanding of hydrologic environment in this area.

Considering the above-mentioned, we have investigated the characteristics of precipitation $^{10), 11)}$ as well as river water $^{11), 12)}$, lagoon waters ${ }^{13)}$, and some groundwater $^{12)}$ samples in Niigata Prefecture by using $\delta^{18} \mathrm{O}$ and other measuring items.

In this paper, to investigate the sources and characteristics of precipitations in Niigata Prefecture in more detail, in addition to regularly sampling conducted every one or two weeks as described in our previous paper ${ }^{11)}$, sequential rainfalls sampling for a short period was preliminarily carried out for five precipitations in any seasons, for instance, during passage of typhoon. For these samples, time-course of $\delta^{18} \mathrm{O}$ was examined during rainfalls; and backward trajectories analyses have been also conducted to estimate the passing route of air mass which bring about the precipitation.

Table 1 Sequentially taken five precipitation samples at the rooftop of Niigata University from July 2006 to October 2007

\begin{tabular}{lcccc}
\hline & Rainfall Date & $\begin{array}{c}\text { Number of } \\
\text { samples }\end{array}$ & $\begin{array}{c}\text { Amount of } \\
\text { precipitation } / \mathrm{mm}\end{array}$ & $\begin{array}{c}\text { Sampling } \\
\text { period / h }\end{array}$ \\
\hline (a)* & July 18-19, 2006 & 5 & 8.2 & 12 \\
(b) & Jan. 6-7, 2007 & 5 & 26.0 & 24 \\
(c)* & May 18-19, 2007 & 7 & 5.5 & 6 \\
(d) & July 21, 2007 & 7 & 6.5 & 4 \\
(e)* & Oct. 4, 2007 & 7 & 6.5 & 5 \\
\hline
\end{tabular}

*These samples were taken during passage of typhoons 


\section{Experimental}

\section{$2 \cdot 1$ Samples}

Precipitation samples have been collected with a filtrating bulk sampler (referred to Fig. 1 in our previous paper ${ }^{10)}$ ) at the rooftop of Niigata University from 1999 to 2008. Furthermore, precipitations from several sampling points in Niigata Prefecture have been supplied as occasional demands by Niigata Prefectural Research Laboratory for Health and Environment since April 1999. In this work, samples in five points (Fig. 1) were examined.

In addition to above samples, some precipitations were taken sequentially for a short period from July 2006 to October 2007. Sequentially taken rainfalls are listed in Table 1. Among these samples, the first, third and fifth precipitations were taken during passage of the No. 5 Typhoon in 2006, the No. 2 Typhoon in 2007, and the No. 15 Typhoon in 2007, respectively ${ }^{14)}$.

\section{$2 \cdot 2$ Analytical Method}

For the measurement of oxygen stable isotope ratios $\left(\delta^{18} \mathrm{O}\right), \mathrm{CO}_{2}-\mathrm{H}_{2} \mathrm{O}$ isotope equilibration method $^{15)}$ was performed. The sample preparation procedure based on the method of Watanabe et al. ${ }^{16)}$ was applied. Isotopic measurements were performed with a stable isotope ratio mass spectrometer (Micromass PRISM).

\section{$2 \cdot 3$ Backward trajectories analyses}

Backward trajectories analyses have been conducted for sequentially taken rainfalls based on "Meteorological Data Explorer (METEX) ${ }^{17)}$ " by Center for Global Environmental Research, National Institute for Environmental Studies.

\section{Results and discussion}

$3 \cdot 1$ Annual or seasonal variation of $\delta^{18} \mathrm{O}$ values in the precipitation

The $\delta^{18} \mathrm{O}$ data for precipitation samples taken from 1999 to 2008 at the rooftop of Niigata University are shown in Table 2 . The $\delta^{18} \mathrm{O}$ values varied between $-25.14 \%$ and $-1.60 \%$ based on each meteorological condition, while the mean value of $\delta^{18} \mathrm{O}$ in each year was from $-8.37 \%$ (in 2006) to $-7.33 \%$ (in 2001). Among these data, $\delta^{18} \mathrm{O}$ of individual precipitation in 2008 is shown in Table 3 along with temperature and the amount of precipitation; and sea-

Table 2 Mean $\delta^{18} \mathrm{O}$ values (\%) of precipitation at the rooftop of Niigata University from 1999 to 2008

\begin{tabular}{ccccc|c}
\hline \multirow{2}{*}{$\begin{array}{c}\text { Sampling } \\
\text { Year }\end{array}$} & Mean & S.D. & Max. & Min. & \multicolumn{2}{c}{ Number } \\
of & Data \\
\hline 1999 & -8.25 & 2.64 & -5.09 & -14.18 & 51 \\
2000 & -7.91 & 3.54 & -2.77 & -25.14 & 80 \\
2001 & -7.33 & 2.15 & -3.63 & -15.44 & 82 \\
2002 & -7.97 & 2.25 & -3.72 & -17.01 & 49 \\
2003 & -7.78 & 2.78 & -1.60 & -14.29 & 43 \\
2004 & -7.69 & 2.61 & -2.49 & -15.24 & 41 \\
2005 & -7.96 & 2.13 & -1.96 & -14.88 & 36 \\
2006 & -8.37 & 1.96 & -3.76 & -14.02 & 43 \\
2007 & -8.05 & 2.69 & -3.82 & -14.19 & 37 \\
2008 & -8.23 & 2.63 & -3.64 & -14.58 & 56 \\
\hline
\end{tabular}


Table $3 \quad \delta^{18} \mathrm{O}$ values of individual precipitation taken in 2008 along with the amount of precipitation and temperature

\begin{tabular}{|c|c|c|c|}
\hline Sample & $\delta^{18} \mathrm{O}$ & precipitation & temperature \\
\hline & $\%$ & $\mathrm{~mm}$ & ${ }^{\circ} \mathrm{C}$ \\
\hline $1 / 1-1 / 9$ & -7.12 & 33.4 & 12.4 \\
\hline $1 / 9-1 / 18$ & -9.90 & 33.4 & 7.1 \\
\hline $1 / 18-1 / 28$ & -8.79 & 12.7 & 9.1 \\
\hline $1 / 28-2 / 8$ & -11.66 & 28.0 & 5.8 \\
\hline $2 / 8-2 / 22$ & -7.99 & 33.4 & 10.6 \\
\hline $2 / 22-3 / 4$ & -11.36 & 33.4 & 8.3 \\
\hline $3 / 4-3 / 15$ & -6.79 & 10.8 & 12.6 \\
\hline $3 / 15-4 / 1$ & -8.27 & 33.4 & 12.7 \\
\hline $4 / 1-4 / 11$ & -9.81 & 15.9 & 14.0 \\
\hline $4 / 11-4 / 21$ & -9.33 & 9.9 & 19.3 \\
\hline $4 / 21-5 / 1$ & -5.41 & 15.9 & 22.9 \\
\hline $5 / 1-5 / 7$ & -11.39 & 12.7 & 23.2 \\
\hline $5 / 7-5 / 15$ & -6.73 & 8.0 & 20.8 \\
\hline $5 / 15-5 / 21$ & -14.04 & 28.3 & 20.6 \\
\hline $5 / 21-5 / 28$ & -11.85 & 19.1 & 20.5 \\
\hline $5 / 28-6 / 1$ & -6.82 & 11.1 & 21.9 \\
\hline $6 / 1-6 / 11$ & -9.82 & 19.4 & 24.0 \\
\hline $6 / 11-6 / 30$ & -14.58 & 31.8 & 24.7 \\
\hline $6 / 30-7 / 7$ & -5.40 & 15.3 & 23.4 \\
\hline $7 / 7-7 / 15$ & -6.96 & 17.5 & 26.8 \\
\hline $7 / 15-7 / 25$ & -5.86 & 15.3 & 25.1 \\
\hline $7 / 25-7 / 31$ & -8.68 & 31.8 & 30.6 \\
\hline $7 / 31-8 / 5$ & -6.37 & 16.9 & 29.7 \\
\hline $8 / 5-8 / 18$ & -7.20 & 31.8 & 27.1 \\
\hline $8 / 18-8 / 19$ & -8.86 & 31.8 & 26.2 \\
\hline $8 / 19-8 / 25$ & -5.58 & 31.8 & 26.3 \\
\hline $8 / 25-8 / 30$ & -5.72 & 6.4 & 27.1 \\
\hline
\end{tabular}

\begin{tabular}{|c|c|c|c|}
\hline $8 / 30-9 / 9$ & -5.25 & 31.8 & 25.9 \\
\hline $9 / 9-9 / 23$ & -8.00 & 33.4 & 25.0 \\
\hline $9 / 23-9 / 26$ & -4.84 & 36.6 & 19.3 \\
\hline $9 / 26-10 / 5$ & -5.09 & 15.6 & 22.7 \\
\hline $10 / 5-10 / 9$ & -8.37 & 17.5 & 26.6 \\
\hline $10 / 9-10 / 11$ & -6.33 & 13.7 & 21.1 \\
\hline $10 / 11-10 / 15$ & -6.78 & 12.7 & 21.0 \\
\hline $10 / 15-10 / 24$ & -5.10 & 25.5 & 22.3 \\
\hline $10 / 24-10 / 27$ & -7.88 & 31.8 & 22.3 \\
\hline $10 / 27-10 / 28$ & -7.77 & 13.7 & 17.7 \\
\hline $10 / 28-10 / 29$ & -6.66 & 26.4 & 19.2 \\
\hline $10 / 29-11 / 4$ & -4.92 & 35.0 & 12.7 \\
\hline $11 / 4-11 / 10$ & -7.35 & 25.5 & 12.8 \\
\hline $11 / 10-11 / 16$ & -7.30 & 11.8 & 17.0 \\
\hline $11 / 16-11 / 17$ & -6.31 & 14.0 & 16.6 \\
\hline $11 / 17-11 / 18$ & -6.87 & 21.0 & 12.7 \\
\hline $11 / 18-11 / 19$ & -10.33 & 22.3 & 11.8 \\
\hline $11 / 19-11 / 20$ & -12.25 & 33.4 & 7.3 \\
\hline $11 / 20-11 / 21$ & -11.36 & 31.8 & 10.9 \\
\hline $11 / 21-11 / 23$ & -10.75 & 26.7 & 8.7 \\
\hline $11 / 23-11 / 25$ & -13.23 & 30.2 & 14.8 \\
\hline $11 / 25-11 / 30$ & -11.84 & 31.8 & 9.7 \\
\hline $11 / 30-12 / 5$ & -14.13 & 21.0 & 9.6 \\
\hline $12 / 5-12 / 9$ & -6.86 & 25.5 & 6.9 \\
\hline $12 / 9-12 / 12$ & -7.05 & 14.3 & 13.7 \\
\hline $12 / 12-12 / 15$ & -3.64 & 10.2 & 7.5 \\
\hline $12 / 15-12 / 22$ & -7.79 & 41.4 & 7.9 \\
\hline $12 / 22-12 / 26$ & -7.55 & 31.2 & 3.4 \\
\hline $12 / 26-1 / 3$ & -7.17 & 14.3 & 9.5 \\
\hline
\end{tabular}
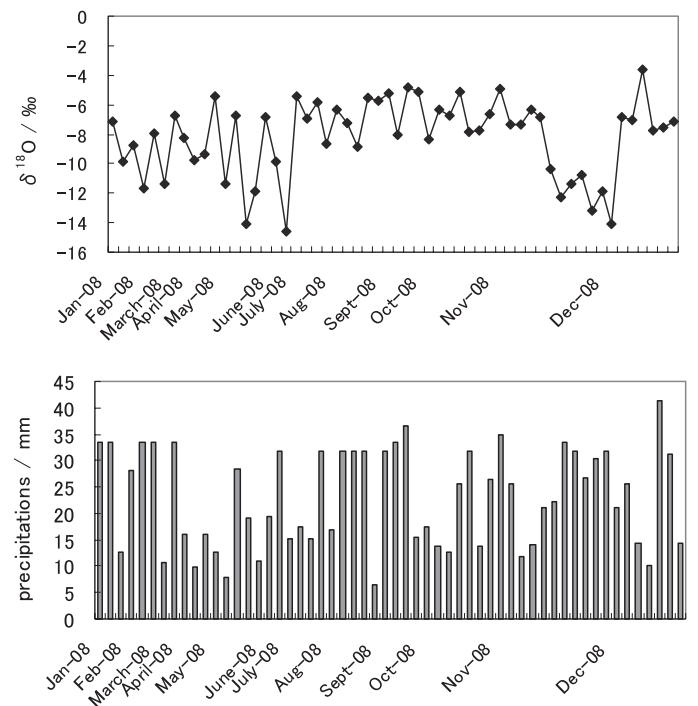

Fig. 2 Seasonal variation of $\delta^{18} \mathrm{O}$ for precipitation taken in 2008 at the rooftop of Niigata University. 

in Niigata prefecture, Japan

Table $4 \delta^{18} \mathrm{O}$ values $(\%)$ of precipitation at 5 sampling points in Niigata Prefecture from April 2001 to March 2003

\begin{tabular}{|c|c|c|c|c|c|c|}
\hline \multirow{2}{*}{\multicolumn{2}{|c|}{ Sampling Date }} & (1) & (2) & (3) & (4) & (5) \\
\hline & & \multicolumn{5}{|c|}{$\delta^{18} \mathrm{O} / \%$} \\
\hline \multirow[t]{20}{*}{2001} & $4 / 2-4 / 16$ & -4.46 & -6.64 & -7.60 & - & -5.56 \\
\hline & $4 / 16 / 4 / 23$ & - & -3.76 & -7.49 & -1.77 & -1.05 \\
\hline & $4 / 23-5 / 7$ & -2.35 & -5.21 & -6.85 & -4.04 & -4.31 \\
\hline & $5 / 7-5 / 21$ & -6.82 & -5.98 & -10.31 & -6.02 & -6.06 \\
\hline & $5 / 21-6 / 4$ & -8.58 & -9.05 & -14.78 & - & -10.38 \\
\hline & $6 / 4-6 / 17$ & -12.59 & -13.29 & -13.15 & -14.12 & -12.19 \\
\hline & $6 / 17-7 / 2$ & -7.97 & -11.13 & -11.78 & -10.25 & -11.58 \\
\hline & $7 / 2-7 / 16$ & -3.90 & -8.85 & -9.21 & -8.49 & -7.19 \\
\hline & $7 / 16-7 / 30$ & - & -5.00 & -8.38 & -7.21 & -7.65 \\
\hline & $7 / 30-8 / 13$ & -4.90 & -6.93 & -6.73 & -5.10 & -7.09 \\
\hline & $8 / 13-8 / 27$ & -7.20 & -5.08 & -7.31 & -6.06 & -5.73 \\
\hline & $8 / 27-9 / 3$ & -4.04 & -6.51 & -7.59 & -5.77 & -7.25 \\
\hline & $9 / 3-9 / 17$ & -4.54 & -7.89 & -8.10 & -5.69 & -7.59 \\
\hline & $9 / 17-10 / 1$ & -3.42 & -5.73 & -6.37 & -4.96 & - \\
\hline & $10 / 1-10 / 15$ & -7.88 & -8.67 & -8.65 & -8.65 & -9.44 \\
\hline & $10 / 15-10 / 29$ & -6.67 & -7.40 & -10.15 & -7.68 & -8.00 \\
\hline & $10 / 29-11 / 12$ & -8.55 & -8.27 & -11.48 & -9.65 & -10.12 \\
\hline & $11 / 12-11 / 26$ & -5.72 & -6.18 & -7.93 & - & -6.60 \\
\hline & $11 / 26-12 / 10$ & -6.51 & -5.78 & -11.73 & -7.84 & - \\
\hline & $12 / 10-12 / 25$ & -8.63 & -7.73 & -8.94 & -8.40 & -7.79 \\
\hline \multirow[t]{9}{*}{2002} & $12 / 25-1 / 7$ & -8.72 & -8.99 & -11.90 & -11.06 & -11.17 \\
\hline & $1 / 7-1 / 21$ & -6.39 & -7.04 & -9.79 & -8.11 & -6.74 \\
\hline & $1 / 21-1 / 28$ & - & -11.27 & -13.46 & -11.98 & -11.18 \\
\hline & $1 / 28-2 / 12$ & -7.17 & -9.67 & -10.52 & -9.54 & -9.00 \\
\hline & $2 / 12-2 / 25$ & -6.67 & -6.50 & -10.27 & -8.49 & -8.36 \\
\hline & $2 / 25-3 / 4$ & -1.92 & -5.80 & -5.10 & - & -3.75 \\
\hline & $3 / 4-3 / 18$ & -12.07 & -9.17 & -8.93 & -10.24 & -9.15 \\
\hline & $3 / 18-4 / 1$ & -10.58 & -9.54 & -9.28 & -10.72 & -10.65 \\
\hline & $4 / 2-4 / 16$ & -4.30 & -5.80 & -7.59 & -5.91 & -5.54 \\
\hline
\end{tabular}

\begin{tabular}{|c|c|c|c|c|c|c|}
\hline & $4 / 16 / 4 / 23$ & -2.89 & -2.56 & -6.40 & -2.09 & -2.35 \\
\hline & $4 / 23-5 / 7$ & -6.30 & -6.53 & -5.74 & -6.22 & -6.02 \\
\hline & $5 / 7-5 / 21$ & -8.09 & -13.30 & -8.46 & -7.44 & -7.24 \\
\hline & $5 / 21-6 / 4$ & -3.34 & -4.39 & -7.51 & -6.42 & -4.97 \\
\hline & $6 / 4-6 / 17$ & -6.05 & -6.04 & -7.80 & -5.00 & -8.25 \\
\hline & $6 / 17-7 / 2$ & -9.81 & -10.25 & -9.77 & -9.34 & -7.02 \\
\hline & $7 / 2-7 / 16$ & -10.61 & -11.64 & -13.19 & -11.41 & -10.39 \\
\hline & $7 / 16-7 / 30$ & -11.12 & -10.32 & -11.21 & -9.67 & -7.91 \\
\hline & $7 / 30-8 / 13$ & -7.26 & -6.41 & -6.09 & -7.25 & -6.08 \\
\hline & $8 / 13-8 / 27$ & -6.97 & -6.47 & -8.58 & -7.18 & -4.82 \\
\hline & $8 / 27-9 / 3$ & -5.81 & -4.97 & -7.39 & -5.49 & -6.17 \\
\hline & $9 / 3-9 / 17$ & -10.14 & -7.23 & -6.92 & -5.58 & -4.95 \\
\hline & $9 / 17-10 / 1$ & -8.27 & -6.39 & -7.75 & -7.89 & -7.57 \\
\hline & $10 / 1-10 / 15$ & -10.81 & -9.99 & -14.91 & -11.47 & -10.61 \\
\hline & $10 / 15-10 / 29$ & -6.25 & -7.82 & -9.71 & -7.48 & -7.04 \\
\hline & $10 / 29-11 / 12$ & -8.56 & -10.97 & -11.86 & -10.26 & -10.60 \\
\hline & $11 / 12-11 / 26$ & -6.20 & -6.84 & -8.92 & -7.63 & -6.54 \\
\hline & $11 / 26-12 / 10$ & -9.12 & -9.70 & -9.88 & -10.35 & -8.59 \\
\hline & $12 / 10-12 / 25$ & -9.13 & -9.65 & -11.62 & -10.23 & -10.34 \\
\hline 2003 & $12 / 25-1 / 7$ & -8.08 & -8.62 & -11.35 & -9.60 & -9.64 \\
\hline & $1 / 7-1 / 21$ & -11.16 & -8.14 & -10.71 & -9.42 & -9.59 \\
\hline & $1 / 21-1 / 28$ & -5.67 & -5.79 & -9.69 & -6.92 & -7.82 \\
\hline & $1 / 28-2 / 12$ & -10.26 & -11.35 & -10.41 & -10.23 & -9.65 \\
\hline & $2 / 12-2 / 25$ & -8.19 & -8.30 & -9.96 & -8.01 & -8.06 \\
\hline & $2 / 25-3 / 4$ & -12.19 & -12.73 & -11.77 & -12.70 & -11.03 \\
\hline & $3 / 4-3 / 18$ & -9.22 & -8.85 & -9.85 & -9.52 & -8.99 \\
\hline & $3 / 18-4 / 1$ & -6.24 & -5.66 & -8.69 & -7.65 & -7.46 \\
\hline & Mean & -7.36 & -7.85 & -9.42 & -8.08 & -7.79 \\
\hline & S.D & 2.62 & 2.41 & 2.24 & 2.52 & 2.37 \\
\hline
\end{tabular}

The number (e.g. (1), (2) $\cdots$ ) in table corresponds to the number of each sampling point $(\bullet)$ in Fig. 1. "-" represents the defect of data due to the lack of sample.

sonal variation of $\delta^{18} \mathrm{O}$ is shown in Fig. 2 .

The $\delta^{18} \mathrm{O}$ values of the precipitation samples at several points in Niigata Prefecture from April 1999 to March 2001 are shown in our previous paper ${ }^{6}$. The $\delta^{18} \mathrm{O}$ values obtained at 5 points from April 2001 to March 2003 are shown in Table 4. It is found that the mean value of $\delta^{18} \mathrm{O}$ at seaside spots (i.e., Niigata City and Joetsu City) or marine spots (i.e., Sado City) is larger than that of inland spots (Shitada Village and Nagaoka City). Particularly, it is notable that the mean value of $\delta^{18} \mathrm{O}$ in Shitada Village $(-9.42 \%)$ is remarkably small compared to that of other points.

Among these data in Table 4, monthly variation of $\delta^{18} \mathrm{O}$ in the precipitation at 3 represen-

tative points (marine spots, seaside spots, inland spots) is presented in Fig. 3. It is found that $\delta^{18} \mathrm{O}$ in Shitada Village are generally small throughout the year. It may reflect that the precipitations in Niigata Prefecture are dominantly affected by "Continental effect" ${ }^{11,10)}$.

From Figs. 2 and 3, the following features have been generally presented in the precipitation in Niigata Prefecture.

(1) In rainy season, when the development of the Bai-u front over Japan is large, $\delta^{18} \mathrm{O}$ values of precipitation are relatively small.

(2) In summer, $\delta^{18} \mathrm{O}$ values of precipitation are generally large, whereas $\delta^{18} \mathrm{O}$ values of precipitation are small in winter. 

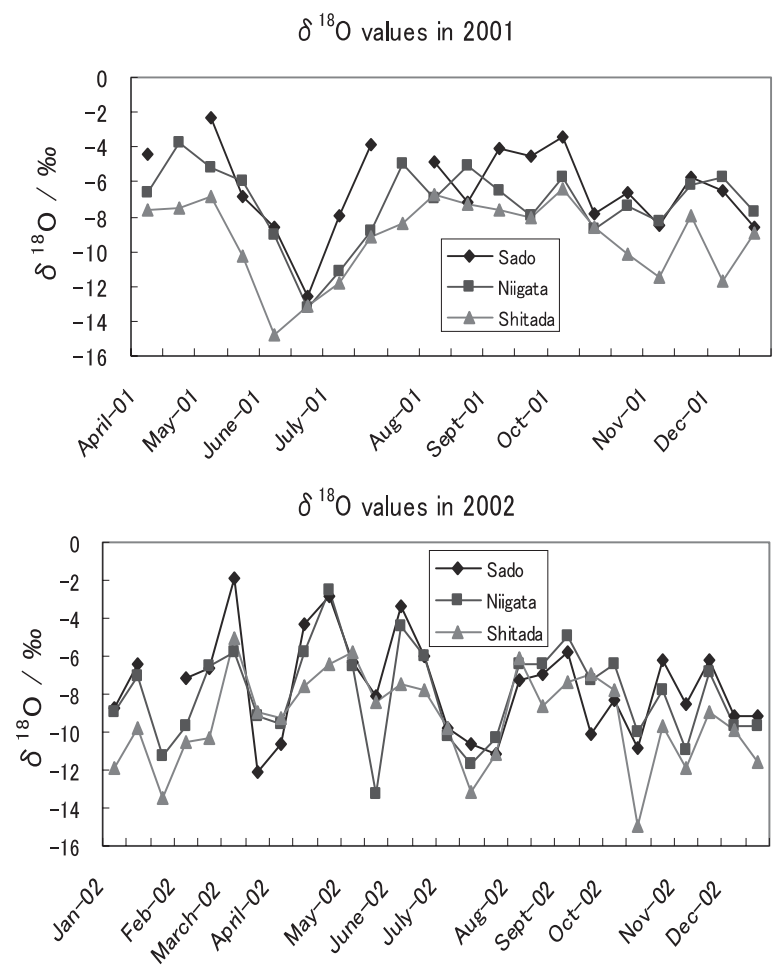

Fig. 3 Monthly variation of $\delta^{18} \mathrm{O}$ values in precipitation at Sado City, Niigata City, and Shitada Village in Niigata Prefecture.

(3) The variation of $\delta^{18} \mathrm{O}$ value in precipitation is generally smaller in winter than in summer at each area in Niigata Prefecture.

In rainy season, it can be considered that the Bai-u front become vague with the movement to northward. Thus low $\delta^{18} \mathrm{O}$ value observed in high latitude (such as Niigata) can be attributed to the effect of "Latitude effect"1),10) as well as “Amount effect"1),10).

In summer, the Pacific high pressure is dominant in Japan. Higher $\delta^{18} \mathrm{O}$ values observed in summer may be related to the development of Pacific High pressure, and predominantly affected by “Temperature effect" ${ }^{1), 10)}$. Liu et al. ${ }^{18)}$ pointed out that $\delta^{18} \mathrm{O}$ value of summer monsoon precipitation in East Asia is relatively larger than that of winter precipitation. Our results are basically in good agreement with the suggestion of Liu et al. ${ }^{18)}$

On the other hand, in winter, the Siberian air mass crosses northern Japan including Niigata Prefecture and the supply route of precipitation is relatively uniform. It may be one of the causes that the variation of $\delta^{18} \mathrm{O}$ in precipitation is generally small in winter.

From the above-mentioned, it can be considered that the variation of $\delta^{18} \mathrm{O}$ values is closely related to the dominance or stability of the air mass in each season.

$3 \cdot 2$ Time-course of $\delta^{18} \mathrm{O}$ values in the precipitation

Time-course of $\delta^{18} \mathrm{O}$ for sequentially sampled precipitations at July $18-19,2006$ is presented in Fig. 4 along with the amount of precipitation. From this figure, it is found that $\delta^{18} \mathrm{O}$ generally 
7/18-19, 2006

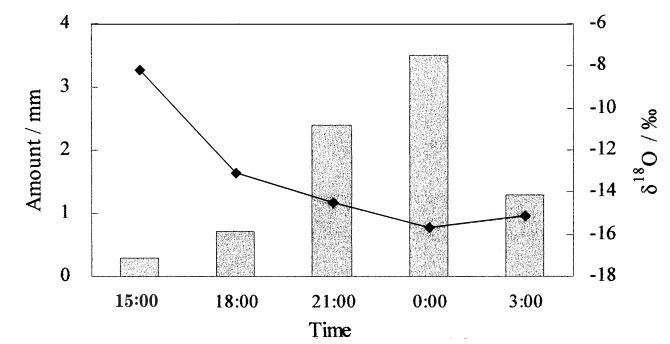

(a)
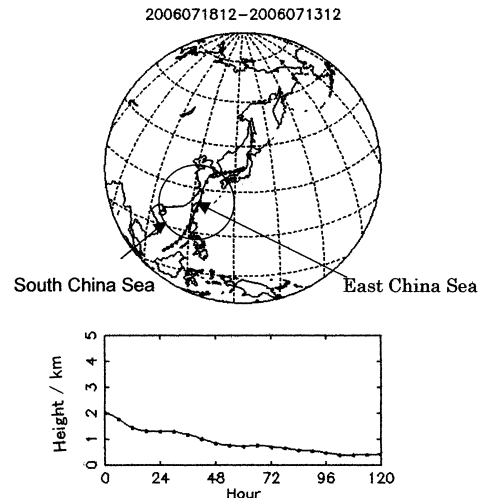

(b)
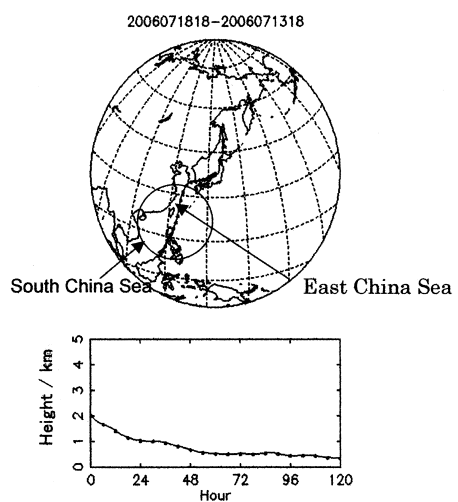

Fig. 4 Timely variation of $\delta^{18} \mathrm{O}$ for sequentially sampled precipitations at July $18-19,2006$ along with the amount of precipitation[(a)]. The backward trajectories are also shown $[(\mathrm{b})$ : the first stage during precipitations, (c) : the latter stage during precipitations].

decreased with time until the final stage. It may eflect the feature as predicted by "Rayleigh model of atmospheric vapor condensation" ${ }^{1), 5)}$. Taking time-course of $\delta^{18} \mathrm{O}$ (Fig. 4 (a) into consideration with the backward trajectories analyses (Fig. 4(b), (c) $)^{17)}$, it is suggested that the series of precipitations might be brought about by the same air mass (i. e., the source is near East China Sea and the passing route is almost constant) during precipitations. Furthermore, the amount of precipitations increased with time until the final stage, suggesting that "Amount effect" ${ }^{1)}{ }^{10}$ ) may be large in the series of precipitations at rainy season.

Time-course of $\delta^{18} \mathrm{O}$ of the sequentially precipitations taken from January 6-7, 2007 is shown in Fig. 5. Contrary to the above case
(Fig. 4(a)), $\delta^{18} \mathrm{O}$ generally increased with time at first, and then decreased. During these precipitations, the air pressure is variable, and the precipitations continued for a long time. Judging from the backward trajectories analyses (Fig. 5(b), (c) $)^{17}$, the source which brought about the precipitation is near Korean peninsula and South of Japan Sea at former stage, whereas the source at latter stage is near Siberia and North of Japan Sea. Time-course of $\delta^{18} \mathrm{O}$ found in Fig. 5 (a) is thus considered to be attributable to the inflow of air having different origin during the series of precipitations.

Time-course of $\delta^{18} \mathrm{O}$ in three precipitations at May 18 -19, July 21 and October 4 in 2007 are presented in Fig. 6. For the precipitations at May $18-19$ in 2007 (Fig. 6 (a)), $\delta^{18} \mathrm{O}$ generally 


\section{1/6-7, 2007}

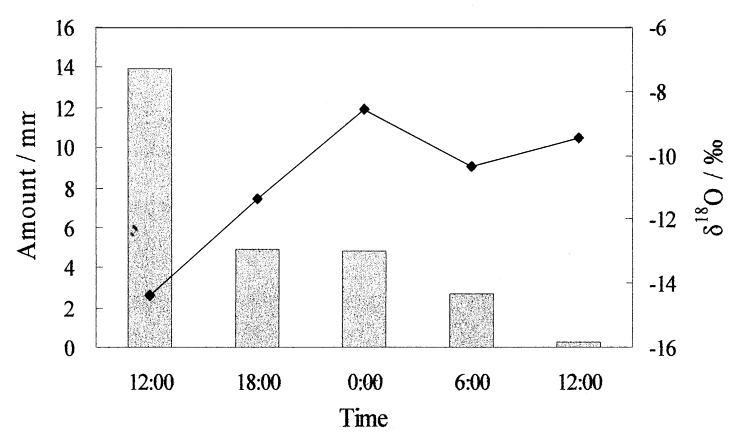

(a)

(b)
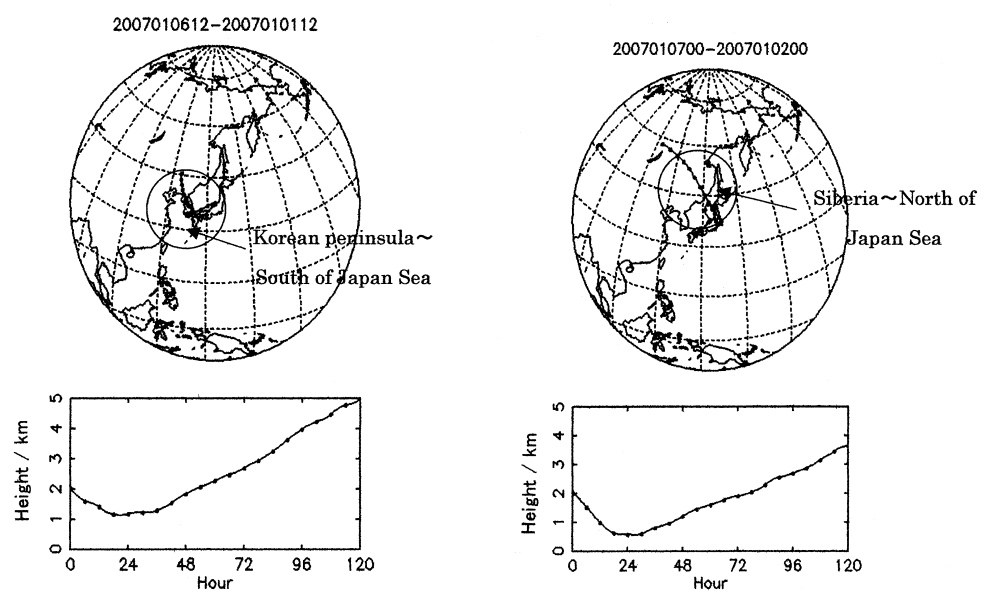

Fig. 5 Timely variation of $\delta^{18} \mathrm{O}$ for sequentially sampled precipitations at January $6-7,2007$ along with the amount of precipitation[(a)]. The backward trajectories are also shown[(b) : the first stage during precipitations, (c) : the latter stage during precipitations].

decreased with time, as predicted by Rayleigh condensation model. It is suggested that the series of precipitations might be brought about by the same air mass during precipitations as in the case of precipitations in July 2006. During the series of precipitations, the backward trajectory ${ }^{17)}$ did not change much, and it extended from the continent of China, Yellow Sea, and Japan Sea. It is considered that the precipitation in spring is affected by air mass having its origin in the continent of China.

In case of the precipitations at July 21 in 2007 (Fig. 6(b)), the variations of $\delta^{18} \mathrm{O}$ was relatively small, and convective supply of air is sug- gested; although $\delta^{18} \mathrm{O}$ value decreased from $-6.30 \%$ to $-8.66 \%$ throughout the precipitations. The backward trajectory ${ }^{17)}$ extended from East China Sea to Japan Sea, and did not change so much during these precipitations. It is suggested that the precipitation in summer is dominantly affected by air mass having its origin in East China Sea.

Figure 6 (c) shows time-course of $\delta^{18} \mathrm{O}$ in the precipitations at October 4 in 2007. $\delta^{18} \mathrm{O}$ generally decreased with time until the final stage. The behavior is similar to that of the case in precipitations at July in 2006 (Fig. 4(a)), and that is also true for Rayleigh condensation 
(a)

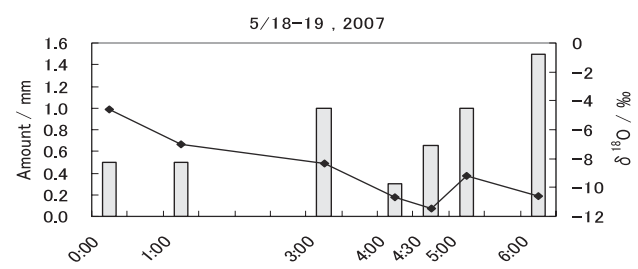

(b)

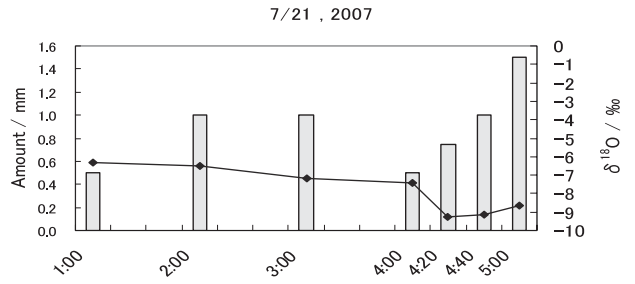

(c)

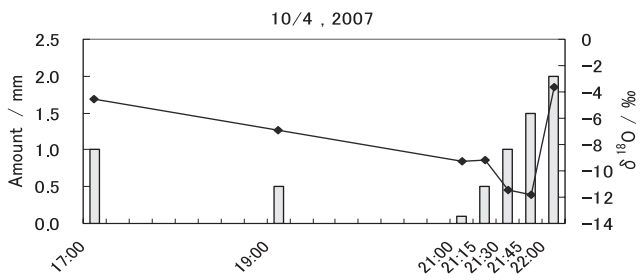

Fig. 6 Timely variation of $\delta^{18} \mathrm{O}$ and the amount of precipitation for sequentially sampled precipitations. (a) : May $18-19,2007$, (b) : July 21, 2007, (c) : October 4, 2007.

model. It is predicted that the precipitations might be brought about by the same air mass during precipitation. The backward trajectory was almost constant during these precipitations, and it existed in Japan Sea based on the backward trajectories analyses ${ }^{17)}$. It is considered that the precipitation in autumn is dominantly affected by air mass having its origin in Japan Sea.

Considering the above-mentioned, it appears that a decreasing heavy isotope (i.e., $\delta^{18} \mathrm{O}$ ) content, as predicted by Rayleigh models of atmospheric vapor condensation, is a predominant feature of sequentially sampled rainfalls, particularly for precipitations taken during passage of typhoons, although further investigations are needed to confirm the relationship be- tween time-course of $\delta^{18} \mathrm{O}$ and meteorological condition in more detail.

From this work, the sources, passing routes (or the characteristics) of precipitations in Niigata Prefecture could be quantitatively clarified to some extent. The data obtained and the method used in this work can be useful for future study and preservation of atmospheric environment.

\section{Acknowledgements}

This work was supported, in part, by Takahashi Industry Economy Research Foundation.

Part of this study was presented at the 44th (July 4-6, 2007, Tokyo), 45th (July 2-4, 2008, Tokyo), and 46th (July 1-3, 2009, Tokyo) “Annual Meeting on Radioisotope and Radiation Research”.

\section{References}

1) Faure, G., Principles of Isotope Geology, pp.429459, John Wiley \& Sons, New York (1986)

2) Hoefs, J., Stable Isotope Geochemistry,pp.103-115, Springer-Verlag, Berlin (1997)

3) Sakai, H. and Matsuhisa, Y., Antei Doitai Chikyukagaku, pp.83-102, Tokyo-Daigaku Syuppan Kai, Tokyo (1995) (in Japanese)

4) Kortelainen, N. M. and Karhu, J. A., J. Hydrol., 285, 143-157 (2004)

5) Dansgaard, W., Tellus, 16, 436-468, (1964)

6) Waseda, A. and Nakai, N., Chikyukagaku, 17, 83-91, (1983) (in Japanese)

7) Celle-Jeanton, H., Gonfiantini, R., Travia, Y. and Sol, B., J. Hydrol ., 289, 165-177 (2004)

8) Suzuki, K. and Endo, Y., Geophys. Res. Lett., 22 (5), 591-594 (1995)

9) Inoue, J., Watanabe, O. and Nakajima, C., Tenki, 33, 641-648 (1986) (in Japanese)

10) Kano, N., Aihara, H., Kojima, R., Takeuchi, K., Sato, A. and Imaizumi, H., RADIOISOTOPES, 52, 65-80 (2003) (in Japanese)

11） Kano, N., Kikuchi, T., Sakamoto, N., Imaizumi, H., 
Murayama, H., Yagoh, H. and Ohizumi, T., RADIOISOTOPES, 55, 307-317 (2006)

12) Kano, N., Sato, A. and Imaizumi, H., RADIOISOTOPES , 53, 415-425 (2004) (in Japanese)

13) Lu, H., Kano, N., Yashima, Y., Amano, Y., Li, C., Imaizumi, H., Watanabe, N. and Zheng, Y., $R A$ DIOISOTOPES, 57, 405-418(2008)

14) Japan Meteorological Agency:Information for typhoon, http://www.data.jma.go.jp/fcd/yoho/ typhoon/index.html

15) Epstein, S. and Mayeda, T., Geochim. Cosmochim.
Acta, 4, 213-224 (1953)

16) Watanabe, N., Yuhara, M., Sato, O., Suzuki, M. and Nakagawa, T., Ann. Rep. Saigai-ken, Niigata Univ., 20, 109-114, (1998) (in Japanese)

17) Center for Global Environmental Research, National Institute for Environmental Studies: Meteorological Data Explorer, http://db.cger.nies. go.jp/metex/index.jp.html

18) Liu, W., Feng, X., Liu, Y., Zhang, Q. and An, Z., Chem. Geol., 206, 73-80 (2004)

要 旨

\title{
新潟県における降水の酸素安定同位体比の特性
}

\author{
李冲, 狩野直樹*, 上野悠一, 花房 充, \\ 焦 玉荣, 今泉 洋*, 渡部直喜** \\ 新潟大学大学院自然科学研究科 \\ * 新潟大学工学部 \\ **新潟大学災害復興科学センター \\ 950-2181 新潟県新潟市西区五十嵐二の町 8050
}

新潟県に㧍ける降水の起源, 供給経路及び地域的・季節的特徴について把握するため, 新潟県降 水の酸素安定同位体比 $\left(\delta^{18} \mathrm{O}\right)$ の短期間での経時変動が年変動, 季節変動とともに調查された。降 水は, 1999 年から 2008 年まで, 主として新潟大学屋上において, ろ過式採水装置により採水され た。更に，連続採取降雨については，後方流跡線による解析も併せて行った。

その結果, 新潟県に扔ける降水について, 主として以下のような特徴が明らかになった。(1) $\delta^{18} \mathrm{O}$ 值は, $-25.14 \%$ ～- $1.60 \%$ の変動を示す。なお，各年の平均值は, $-8.37 \%$ （2006 年）～- $7.33 \%$ （2001 年）であった。(2) 地域間の比較では, 臨海地域（新潟市, 上越市）あるいは海洋地域（佐 渡市）の $\delta^{18} \mathrm{O}$ の平均值は, 内陸地域（下田村, 長岡市）に比べて, 高い值を示す。(3) $\delta^{18} \mathrm{O}$ 值は, 概して, 梅雨期に低く, 夏期に相対的に高く, 冬期に低い值を示す傾向が見られた。(4)連続採取 降雨では, Rayleighの蒸留モデルから予想されるように, 時間とともに $\delta^{18} \mathrm{O}$ が下降する傾向が主 要な特徴で, 特に台風時の試料においては, そのような傾向を示した。 